Jurnal Teknologi Laboratorium

Vol.9, No.2, 2020, pp. $168-175$

ISSN 2580-0191(Online), ISSN 2338 - 5634(Print)

DOI: 10.29238/teknolabjournal.v9i2.204

Journal homepage: https://www.teknolabjournal.com/index.php/Jt//index

Original Research.

open 1 Access

\title{
Detection of B1 gene as Toxoplasmosis marker in women of childbearing age in West Bandung Regency, Indonesia
}

\section{Patricia Gita Naully ${ }^{a^{*}}$, Selvi Anggraeni Supendi ${ }^{\mathrm{b}}$}

Department of Medical Laboratory Technology, School of Health Sciences, Jenderal Achmad Yani Cimahi, Indonesia

a E-mail address: patriciagitanaully@gmail.com

bE-mail address: selvishys@gmail.com

\section{HIGHLIGHTS}

- B1 gene was detected in 7 of 50 women of childbearing age in West Bandung Regency

- Transmission of Toxoplasma gondii in the area is influenced by frequent contact with pets

\section{ARTICLE INFO}

\section{Article history}

Received Date: Feb $10^{\text {th }}, 2020$

Revised Date: Oct $15^{\text {th }}, 2020$

Accepted Date: Nov 02 ${ }^{\text {nd }}, 2020$

\section{Keywords:}

B1 gene

PCR

Toxoplasmosis

Childbearing age women

\begin{abstract}
A B S T R A C T
Congenital toxoplasmosis can cause damage and death to the fetus, to prevent this case, toxoplasmosis testing is important for the woman of childbearing age. One of the methods to screening the presence of $T$. gondii in the blood is Polymerase Chain Reaction (PCR). One of the $T$. gondii genes which can be used as a marker is the B1 gene. There are many toxoplasmosis cases in Indonesia, but the data is still difficult to find in West Bandung Regency. This study aimed to determine the number of toxoplasmosis cases in a woman of childbearing age in West Bandung Regency using the B1 gene as a marker and to determine the factors that influence these cases by conducting statistical analysis on the results of the questionnaire. The sample used in this study was 50 women of childbearing age (got married and domiciled in West Bandung). All samples have met the inclusion criteria and signed the informed consent. DNA from blood specimens was isolated using the Wizard Genomic DNA Purification Kit. The concentration and purity of isolated DNA were measured using a nanodrop device. Besides, the B1 gene from T. gondii was amplified using a pair of specific primers and visualized by the agarose electrophoresis method. Data were analyzed using the logistic regression method. The results showed that 7 women of childbearing age women (14\%) in West Bandung Regency had toxoplasmosis. Frequent contact with pets, especially cats, was a significant factor $(p<0.005)$ in this disease transmission.
\end{abstract}

This is an open-access article under the CC-BY-SA license.

\author{
${ }^{*}$ Corresponding Author: \\ Patricia Gita Naully \\ Jurusan D4 Teknologi Laboratorium Medik Stikes Jenderal Achmad Yani Cimahi, \\ JIn. Terusan Jenderal Sudirman, Cimahi, Indonesia. \\ Email: patriciagitanaully@gmail.com
}

\section{INTRODUCTION}

Toxoplasmosis is the most common parasitic infection in the world. Until now, 1/3 of the world population is estimated to have this infection. ${ }^{1}$ Moreover, Sakikawa et al 2 ., showed the prevalence of toxoplasmosis in the world, ranging from 6.1 to $74.5 \%$. Toxoplasmosis is a 
zoonotic disease caused by obligate intracellular protozoa, Toxoplasma gondii. There are 3 types of $T$. gondii, such as tachyzoite (the proliferative form), cyst (containing bradyzoite), and oocyst (containing sporozoites). $\frac{3}{}$ The main host of $T$. gondii is a cat ${ }^{4}$ but humans and the other warm-blooded vertebrates (goats, pigs, dogs, chickens, or birds) can be intermediaries. $,-6,7$ Humans can become infected with $T$. gondii by consuming food or water contaminated with cat feces, $, \underline{8}, \underline{9}$ raw meat or vegetables,,$-\frac{7}{}$ and non-pasteurized milk. $\underline{10}$

Toxoplasmosis is divided into five categories, such as toxoplasmosis in immunocompetent, immunocompromised, pregnant, ocular, and congenital patients. $\frac{3}{}$ Congenital Toxoplasmosis is a disease occurred in a fetus due to T. gondii from the mother. In unexposed pregnant women, $T$. gondii can transfer to the fetus through the placenta.? Hide et al., $\frac{11}{1}$ stated that the transmission rate of congenital toxoplasmosis can reach $19.8 \%$. Moreover, congenital toxoplasmosis is the most dangerous type because it can cause miscarriage,,$\underline{5,9}$ visual damage,,$\frac{1,3}{3}$ and nerve damage in the infant, like hydrocephalus, mental retardation, cerebral calcification, and chorioretinitis., ${ }^{2,10}$ Gargate $^{7}$ also stated that congenital toxoplasmosis can affect neurological disorders, particularly schizophrenia, and bipolar disorder. To prevent the adverse effects on the fetus, some studies suggested that toxoplasmosis testing is performed on childbearing age women before being fertilized. $\frac{18}{18}$

In 2014, 56,737-176,882 children per year in India are estimated to have a risk of congenital toxoplasmosis infection. - Furthermore, in Ethiopia, infant mortality due to toxoplasmosis is around 28 cases of 1000 births. $\frac{10}{}$ Besides, congenital toxoplasmosis also occurs in Indonesia, with different prevalence in each region, as $58 \%$ in Surabaya, $70 \%$ in Jakarta, and $80.2 \%$ in Bandung. .12 West Bandung is one of the regencies in West Java having 804,219 female population and $1-11 \%$ couples of childbearing age in each district. $\frac{13}{}$ Most of the population live together with pets or livestock and have a less hygienic lifestyle. It is possible that women in West Bandung infected by $T$. gondii but until now the data of toxoplasmosis in this area are difficult to find.

$T$. gondii presence in the body can be detected by the serological test, as an Indirect Fluorescent Antibody Test (IFAT) or Enzyme-Linked Immunosorbent Assay (ELISA). 4 The component detected in the serological test is the antibody. So, this test often shows the falsenegative result in the initial infection and immunocompromised patient., 14 Therefore, some previous studies suggested that toxoplasmosis can be checked by PCR. $\underline{15}, \underline{16}, 17$ Moreover, Rahumatullah et al.,,$\underline{4}$ and Mousavi et al.,,$\underline{4}$ stated that PCR was used to detect and identify parasites from various specimens, as blood amniotic fluid. Bourdin et al., $\frac{16}{}$ also showed that PCR successfully detected the presence of $T$. gondii in immunocompromised patients.

The B1 gene is one of the genes which can be used as a marker to detect toxoplasmosis. This gene has been widely recommended by several researchers because of consisting of 35 copies in one $T$. gondii cell. $, 15,17$ A high number of gene copies can increase the detection sensitivity. Based on observations, research on toxoplasmosis in women of childbearing age in West Bandung Regency using PCR detection techniques and the B1 gene as a marker has never been done before. Therefore, this study aimed to determine the number of toxoplasmosis cases in a woman of childbearing age in West Bandung Regency using the B1 gene as a marker and to determine the factors that influence these cases by conducting statistical analysis on the results of the questionnaire.

\section{MATERIAL AND METHOD Population and samples}

The population of this study was the childbearing age women domiciled in West Bandung. There were several inclusion criteria used in the selection of the samples, such as willing to be involved in the research, getting married, having age between 20 and 45 years, and having pets (cat, dog, goat, chicken, or bird). Then, 50 samples were collected in this study. All samples had known the background, objective, benefit, and research procedure also signed the informed consent. 


\section{Materials and equipment}

The materials used in this study was agarose (Thermo Scientific), Buffer TAE (Thermo Scientific), Buffer $\mathrm{MgCl}_{2}$ (Thermo Scientific), $\mathrm{ddH}_{2} \mathrm{O}$ (Thermo Scientific), dNTPs (Thermo Scientific), DNA Taq Polymerase (Thermo Scientific), Genomic DNA Isolation Kit (Promega Wizard Genomic DNA Purification Kit), Ladder (Thermo Scientific Gene Ruler 100 bp), Loading dye (BioRad), and Primer (Thermo Scientific) (Table 1).

Table 1. Primer Specifications

\begin{tabular}{ccc}
\hline Primer & \multicolumn{1}{c}{ DNA Sequence } & Amplicon size (bp) \\
\hline B1 Forward Primer & 5'-GGAACTGCATCCGTTCATGAG-3' & 200 \\
B1 Reverse Primer & 5'-TCTTTAAAGCGTTCGTGGTC-3' &
\end{tabular}

Furthermore, the tools used in this study were the vacutainer needle (BD Vacutainer), micropipette (BioRad), microtube (Biologix), nanodrop (Thermo Scientific, Nanodrop 2000 Spectrophotometer), a set of electrophoresis (Mupid-EXU), a vacutainer tube (One Med), thermocycler (Thermo Fisher Scientific), UV transilluminator (Avenge).

\section{Research steps}

The research was started by filling out the questionnaire by all participants. The questionnaire used consisted of several questions related to identity, lifestyle (including the transmission risk factor of $T$. gondii), types of pets or livestock, and the disease history. Then, the specimen of venous blood from the participant was taken after this stage.

The genomic DNA was isolated by DNA isolation Kit. Then, the concentration and purity of isolated DNA were measured by nanodrop. Moreover, the B1 gene was amplified by the same primer as the study of Bin Dajem and Almushait, but modifying some of the reaction composition and amplification conditions. The total volume of the amplification reaction was

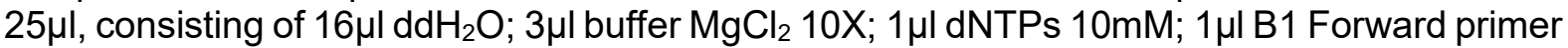
$10 \mathrm{mM}$; $1 \mu \mathrm{l} \mathrm{B1}$ Reverse primer $10 \mathrm{mM}$; $1 \mu \mathrm{l}$ Taq DNA Polymerase $5 \mathrm{U} / \mu \mathrm{l}$; and $2 \mu \mathrm{l}$ sample with DNA concentrations of at least $50 \mathrm{ng} / \mu \mathrm{l}$.

The amplification process started with the pre-denaturation of DNA for 5 minutes at $95^{\circ} \mathrm{C}$. Then, the amplification was carried out as 40 cycles, consisting of denaturation at $95^{\circ} \mathrm{C}$ for 30 seconds, annealing at $55^{\circ} \mathrm{C}$ for 30 seconds, and elongation at $72^{\circ} \mathrm{C}$ for 30 seconds. The final elongation was carried out for 1 minute at $72^{\circ} \mathrm{C}$. The amplification results were visualized by the electrophoresis, with the agarose concentration of $1 \%$. All stages from sample collection to analysis results followed the applicable code of ethics and received approval from the Health Research Ethics Committee of School of Health Sciences number 09/KEPK/V/2019.

\section{Data analysis}

To find out the significantly influential factors with the $T$. gondii transmission in the women of childbearing age in West Bandung, the questionnaire data and the B1 gene amplification were analyzed by logistic regression method, using statistical software.

\section{RESULTS AND DISCUSSION}

Based on the B1 gene amplification result in 50 blood specimens from the women of childbearing age in West Bandung, 7 women (14\%) were positively infected by $T$. gondii. There was a 200 bp DNA band in 7 positive samples. The size of the DNA band was the same as the positive control and the pre-designed amplicon size (Table 1). The positive control used in this study was the genomic DNA from the blood of patients positive to toxoplasmosis. The patients had proven positively infected in the anti- $T$. gondii IgM testing. The amplicon B1 gene process in this study was specifically, where there was no DNA band in the negative control. The negative control used was $\mathrm{dd}_{2} \mathrm{O}$. 


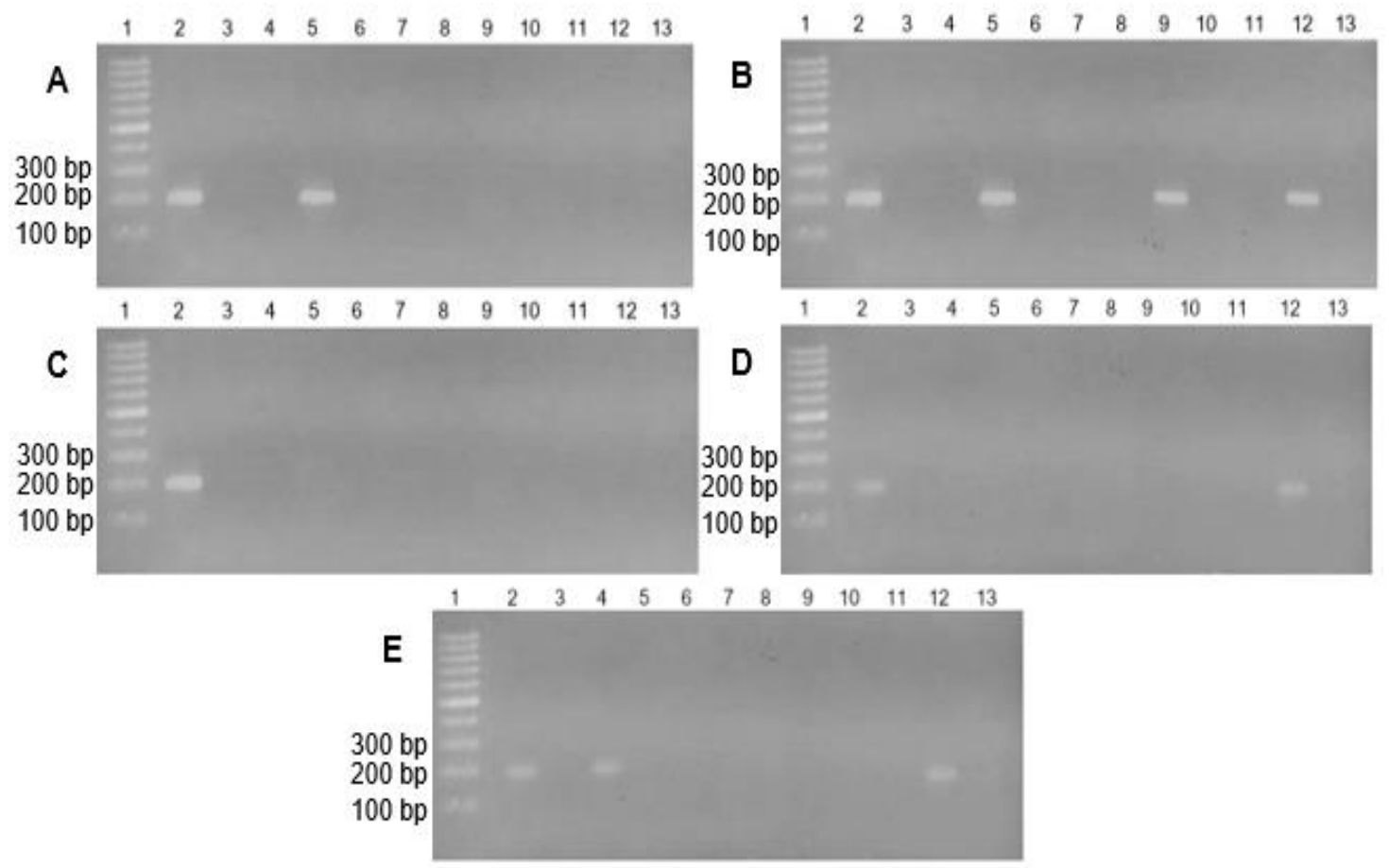

Figure 1. Agasore Electrophoresis Result of the B1 Gene Amplification in Childbearing Age Women in West Bandung

Lane 1: Ladder Thermo Scientific 100 bp; Lane 2: Positive Control; Lane 3: Negative Control.

Lane 4-13: (A) sample number 1-10; (B) sample number 11-20; (C) sample number 21-30; (D) sample number 31-40; (E) sample number 41-50.

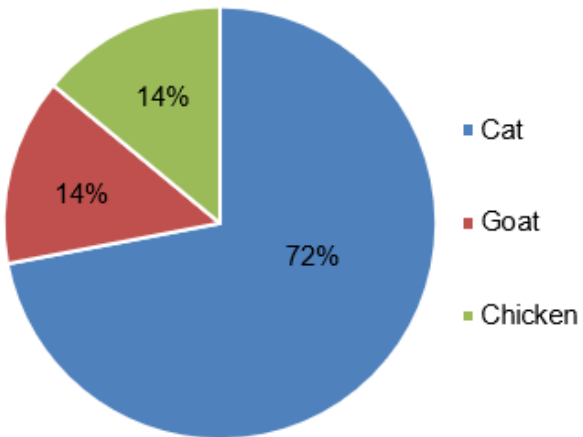

Figure 2. The pet types of the women of childbearing age infected by Toxoplasma gondii in West Bandung Regency

Based on the data, it was known that all woman samples had pets or livestock. All samples infected with $T$. gondii admitted that they raised cats, chickens, and goats, in which the three animals were the most raised by the toxoplasmosis women in West Bandung Regency (Figure 2).

All women also admitted that they often contacted the animals. The animals they had were rarely bathed, did not have the litter box, and could go in and out of the house. Besides, the samples also carried out other activities, like consuming raw meat and vegetables and contacting soil (Table 2). The statistical analysis showed that frequent contact with the animal, especially cat was a factor that significantly related to the $T$. gondii transmission $(P<0.005)$. 
Table 2. Characteristics of Samples

\begin{tabular}{|c|c|c|c|c|c|c|}
\hline \multirow[b]{2}{*}{ Variable } & \multicolumn{3}{|c|}{ Total } & \multicolumn{3}{|c|}{ Toxoplasma gondii infection } \\
\hline & $\mathrm{n}$ & $\%$ & $\mathrm{~N}$ & $\%$ & $\begin{array}{c}\text { Regression } \\
\text { coefficient }\end{array}$ & $p$-value \\
\hline The tenure of pets or livestock & & & & & 0.1053 & 0.1337 \\
\hline$<1$ year & 17 & 34 & 1 & 5.8 & & \\
\hline$>1$ year & 33 & 66 & 6 & 18.2 & & \\
\hline In contact with pets or livestock & & & & & 0.3239 & 0.0117 \\
\hline Frequently & 18 & 36 & 7 & 38.8 & & \\
\hline Infrequently & 11 & 22 & 0 & 0 & & \\
\hline Never & 21 & 42 & 0 & 0 & & \\
\hline Bathing pets or livestock & & & & & 0.3313 & 0.1129 \\
\hline Frequently & 8 & 16 & 0 & 0 & & \\
\hline Infrequently & 17 & 34 & 2 & 11.7 & & \\
\hline Never & 25 & 50 & 5 & 20 & & \\
\hline The abode of pets or livestock & & & & & 0.0019 & 0.4228 \\
\hline Always inside the house & 2 & 4 & 0 & 0 & & \\
\hline In and out of the house & 14 & 28 & 5 & 35.7 & & \\
\hline Always outside the house & 34 & 68 & 2 & 5.8 & & \\
\hline Providing the litter box & & & & & 0.1187 & 0.0914 \\
\hline Yes & 23 & 46 & 0 & 0 & & \\
\hline No & 27 & 54 & 7 & 28 & & \\
\hline Consuming raw vegetables & & & & & 0.4412 & 0.0954 \\
\hline Yes & 36 & 72 & 3 & 8.3 & & \\
\hline No & 14 & 28 & 4 & 28.5 & & \\
\hline Consuming raw meat & & & & & 0.4451 & 0.7719 \\
\hline Yes & 3 & 6 & 3 & 100 & & \\
\hline No & 47 & 94 & 4 & 8.5 & & \\
\hline Contacting with soil & & & & & 0.0448 & 0.7323 \\
\hline Yes & 10 & 20 & 5 & 50 & & \\
\hline No & 40 & 80 & 2 & 5 & & \\
\hline
\end{tabular}

Toxoplasmosis can be detected by many methods. Furthermore, the earliest detection method developed is cell inoculation in culture and microscopy, but these methods are timeconsuming, expensive, and less sensitive. There are also Giemsa and Haematoxylin \& Eosin Staining. Both methods are simple and cost-effective, but the samples used only feces, water, and other environmental materials. 18 Therefore, the researchers use the serological test to detect $T$. gondii antibody circulating. The serological test performance is quite good but has several drawbacks. The serological tests often show false-negative results at the first infection, because the human body takes 1-2 weeks to form the anti- T. gondii IgM (window period). 18 The false-negative result is often found in people with immune systems disorder because their bodies are slow or failed to produce the lgM or lgG. Testing of anti-T. gondii IgM cannot show the active phase of the parasite because the IgM can survive for several months until more than 1 year. $\frac{19}{}$

This study proved that the molecular examination method, like PCR, can be used as an alternative method for detecting toxoplasmosis. Moreover, PCR is more sensitive, specific, and no time-consuming. PCR has also been shown to detect $T$. gondii DNA in the blood of pregnant or unpregnant women. $\frac{5}{}$ Now, many PCR types were developed to detect the toxoplasmosis, like nested PCR and quantitative PCR. Both methods are more sensitive than conventional PCR, but conventional PCR is more desirable because of simpler, faster, and relatively cheaper. Therefore, Rahumatullah et al., 14 stated that conventional PCR is suitable for routine detection of $T$. gondii, especially in developing countries such as Malaysia and Indonesia. The success of the PCR is determined by several factors, like the number of marker gene copies. $\frac{15}{15}$

The B1 gene used as a marker in this study has been widely recommended by researchers. Mousavi et al., ${ }^{4}$ reported that the $B 1$ gene is a specific gene for detecting $T$. gondii, and it is conserved in all strains. Some studies also report that the detection of the B1 
gene is more sensitive than the rDNA, ${ }^{14} \mathrm{P} 30, \underline{5}$ and 529 RE.,$\frac{4,15}{} \mathrm{PCR}$ method using $\mathrm{B} 1$ as a target gene can detect 10 parasites in 100,000 human leukocyte cells. $\frac{14}{}$ On the other hand, some studies further suggested using the $529 \mathrm{RE}$ gene to increase the sensitivity due to the greater number of copies (200-300 copies of genes in one T. gondii cell). $\frac{17, \underline{18}}{10}$ Moreover, Rahumatullah et al., $\frac{14}{4}$ reported that the difference in sensitivity and specificity level of PCR in every study can be influenced by several factors (like the annealing temperature and the

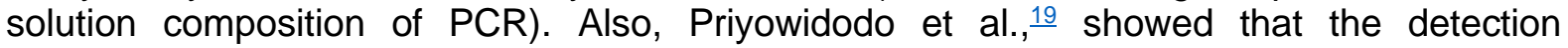
performance of PCR in blood specimens can be influenced by inhibitors (like immunoglobulins, polypeptides, and lactoferrin which can reduce the sensitivity of detection).

The number of women found positive to toxoplasmosis of childbearing age in West Bandung is lower than the other regions, such as Venezuela,,$-\frac{8}{-}$ Kosovo, ${ }^{20}$ Ethiopia,,$\underline{6}$ India, $\stackrel{9}{ }$ and Saudi Arabia. $\stackrel{21}{ }$ The difference in the prevalence rate of every study can be caused by several factors, including method, number, and characteristics of the samples used. Some studies used more than 100 samples, with a wider age range of $11-45$ years.

In this study, the significant factor influencing the T.gondii transmission was the frequent contact with pets, especially cats. This result was in line with Subasinghe et al., $\underline{22}$ in Sri Lanka. Furthermore, the majority of the seropositive respondent of toxoplasmosis had contacted cats at home and outside. Diaz-Suarez and Estevez $z^{-}$also stated that T.gondii inspection is strongly influenced by oocysts in cat feces. The rarely bathed cat can increase the risk of $T$. gondii transmission because the feces can stick to the fur, nails, and body of the cat. Besides, the misplaced cat feces can contaminate soil and water in the surrounding environment, so increasing T. gondii infection. ${ }^{-9}$ Agustin and Mukono $\underline{23}$ reported that cat feces left in the environment can produce infective oocysts. Oocyte can survive for years in soil, sand, and water. The maturation and transmission of oocyte will be faster in humid and wet conditions.,$\underline{71}$ Covering the cat feces with soil or sand cannot prevent the sporulation of oocyst. This only delays the oocyst to sporulate. .24

Besides in contact with the cat or other pets, consuming raw meat and vegetables can increase the toxoplasmosis risk. In this study, these activities did not show a significant effect on the $T$. gondii transmission. However, Sakikawa et al., ${ }^{2}$ reported that consuming raw meat and vegetables was the major factor in the transmission of $T$. gondii in women in Japan. Therefore, it is suggested that the women of childbearing age limit their physical contact with pets which can be the $T$. gondii host, and also do not consume raw meat and vegetables.

\section{CONCLUSION}

Seven of 50 women of childbearing age (14\%) in West Bandung were infected by Toxoplasma gondii. Frequent contact with pets (especially cats) was a significant factor in toxoplasmosis transmission $(p<0.005)$. The results of this study are useful for the Health Office and the public, especially the people in West Bandung Regency, to know the number of cases and the factors that influence toxoplasmosis in the area. The community, especially women of childbearing age, can prevent toxoplasmosis. Besides, this study provides information about alternative methods that can be used to detect $T$. gondii.

\section{DISCLOSURE STATEMENT}

The authors declare that they have no conflict of interest.

\section{ACKNOWLEDGEMENT}

The acknowledgment was given to the West Bandung Regency Integrated Services Post and patients that have been participated in this research.

\section{FUNDING INFORMATION}

The authors declared that this case has received no financial support. 


\section{REFERENCES}

1. Cong W, Dong X-Y, Meng Q-F, et al. Toxoplasma gondii Infection in Pregnant Women: A Seroprevalence and Case-Control Study in Eastern China. Biomed Res Int. 2015;2015:1-6. doi:10.1155/2015/170278.

2. Sakikawa M, Noda S, Hanaoka M, et al. Anti-Toxoplasma Antibody Prevalence, Primary Infection Rate, and Risk Factors in a Study of Toxoplasmosis in 4,466 Pregnant Women in Japan. Clin Vaccine Immunol. 2012;19(3):365-367. doi:10.1128/CVI.0548611.

3. Yuliawati I, Nasronudin N. Pathogenesis, Diagnostic and Management of Toxoplasmosis. Indones J Trop Infect Dis. 2015;5(4):100. doi:10.20473/ijtid.v5i4.2008.

4. Mousavi M, Saravani R, Jafari Modrek M, Shahrakipour M, Sekandarpour S. Detection of Toxoplasma gondii in Diabetic Patients Using the Nested PCR Assay via RE and B1 Genes. Jundishapur J Microbiol. 2016;9(2). doi:10.5812/jim.29493.

5. Bin Dajem SM, Almushait MA. Detection of Toxoplasma gondii DNA by PCR in blood samples collected from pregnant Saudi women from the Aseer region, Saudi Arabia. Ann Saudi Med. 2012;32(5):507-512. doi:10.5144/0256-4947.2012.14.7.1200.

6. Gebremedhin EZ, Abebe AH, Tessema TS, et al. Seroepidemiology of Toxoplasma gondiiinfection in women of child-bearing age in central Ethiopia. BMC Infect Dis. 2013;13(1):101. doi:10.1186/1471-2334-13-101.

7. Gargaté MJ, Ferreira I, Vilares A, et al. Toxoplasma gondii seroprevalence in the Portuguese population: comparison of three cross-sectional studies spanning three decades. BMJ Open. 2016;6(10):e011648. doi:10.1136/bmjopen-2016-011648.

8. Diaz-Suárez $O$, Estevez J. Seroepidemiology of toxoplasmosis in women of childbearing age from a marginal community of Maracaibo, Venezuela. Rev Inst Med Trop Sao Paulo. 2009;51(1):13-17. doi:10.1590/S0036-46652009000100003.

9. Singh S, Munawwar A, Rao S, Mehta S, Hazarika NK. Serologic Prevalence of Toxoplasma gondii in Indian Women of Child Bearing Age and Effects of Social and Environmental Factors. Ghedin E, ed. PLoS Negl Trop Dis. 2014;8(3):e2737. doi:10.1371/journal.pntd.0002737.

10. Fenta DA. Seroprevalence of Toxoplasma gondii among pregnant women attending antenatal clinics at Hawassa University comprehensive specialized and Yirgalem General Hospitals, in Southern Ethiopia. BMC Infect Dis. 2019;19(1):1056. doi:10.1186/s12879-019-4694-8.

11. HIDE G, MORLEY EK, HUGHES JM, et al. Evidence for high levels of vertical transmission in Toxoplasma gondii. Parasitology. 2009;136(14):1877-1885. doi:10.1017/S0031182009990941.

12. Resnhaleksmana E, Nursardjan N, Danuyanti I.G.A.N. Studi Toxoplasmosis pada Penderita Schizophrenia di Rumah Sakit Jiwa Provinsi NTB. J Kesehat Prima. 2014;8(1):1239-1245. doi:10.32807/jkp.v8i1.46.

13. Badan Pusat Statistik. Kabupaten Bandung Barat Dalam Angka 2018.; 2018.

14. Rahumatullah A, Khoo BY, Noordin R. Triplex PCR using new primers for the detection of Toxoplasma gondii. Exp Parasitol. 2012;131(2):231-238.

doi:10.1016/i.exppara.2012.04.009.

15. Wahab T, Edvinsson B, Palm D, Lindh J. Comparison of the AF146527 and B1 Repeated Elements, Two Real-Time PCR Targets Used for Detection of Toxoplasma gondii. J Clin Microbiol. 2010;48(2):591-592. doi:10.1128/JCM.01113-09.

16. Bourdin C, Busse A, Kouamou E, et al. PCR-Based Detection of Toxoplasma gondii DNA in Blood and Ocular Samples for Diagnosis of Ocular Toxoplasmosis. J Clin Microbiol. 2014;52(11):3987-3991. doi:10.1128/JCM.01793-14.

17. Gomez CA, Sahoo MK, Kahn GY, et al. Dual-target, real-time PCR for the diagnosis of intraocular Toxoplasma gondii infections. Br J Ophthalmol. 2019;103(4):569-572. doi:10.1136/bjophthalmol-2018-313064.

18. Liu Q, Wang Z-D, Huang S-Y, Zhu X-Q. Diagnosis of toxoplasmosis and typing of Toxoplasma gondii. Parasit Vectors. 2015;8(1):292. doi:10.1186/s13071-015-0902-6.

19. Priyowidodo D, Hartati S, Kusumawati A, Prastowo J. Diagnosis of Congenital 
Toxoplasmosis Based on Surface Antigen -1 Gene of Local Isolate Toxoplasma Gondii Using Polymerase Chain Reaction. $J$ Vet. 2015;16(3):303-309. https://ojs.unud.ac.id/index.php/ivet/article/view/15997.

20. Dentico P, Volpe A, Putoto G, et al. Toxoplasmosis in Kosovo pregnant women. New Microbiol. 2011;34(2):203-207. http://www.ncbi.nlm.nih.gov/pubmed/21617833.

21. Alzaheb R. Seroprevalence of Toxoplasma gondii and its associated risk factors among women of reproductive age in Saudi Arabia: a systematic review and meta-analysis. Int J Womens Health. 2018; Volume 10:537-544. doi:10.2147/IJWH.S173640.

22. Subasinghe S, Karunaweera N, Kaluarachchi A, et al. Toxoplasma gondii seroprevalence among two selected groups of women. Sri Lankan J Infect Dis. 2011;1(1):9. doi:10.4038/sliid.v1i1.3091.

23. Agustin PD, Mukono J. Description Between Cats Exposure with Toxoplasmosis Disease on Cats Owner and Not- Cats Owner in Mulyorejo Subdistrict, Surabaya City. J Kesehat Lingkung. 2016;8(1):103. doi:10.20473/jkl.v8i1.2015.103-117.

24. Ernawati, Ernawati. Toxoplasmosis, Terapi Dan Pencegahannya. J Ilmiah Ked Wijaya Kusuma.2011;edisi khusus.

\section{SHORT BIOGRAPHY}

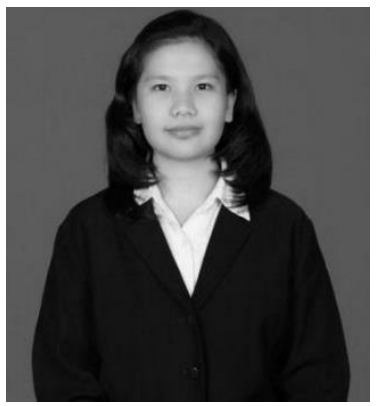

Patricia Gita Naully, Completed her Bachelor's degree in Microbiology Study Program, School of Life Sciences and Technology, Bandung Institute of Technology in 2014. She joined the fast track program in Biotechnology Study Program, School of Life Sciences and Technology, Bandung Institute of Technology and completed her master's degree in 2015. Since 2016, she became a lecturer in Medical Laboratory Technology Study Program, Jenderal Achmad Yani College of Health Sciences. Subjects taught Cell Biology, Molecular Biology, Immunology, Virology, and Bioinformatics. Actively researching in the fields of detection of sexually transmitted infections using serological and molecular methods, development of molecular methods for detecting pathogens, and development of hepatitis $B$ vaccine.

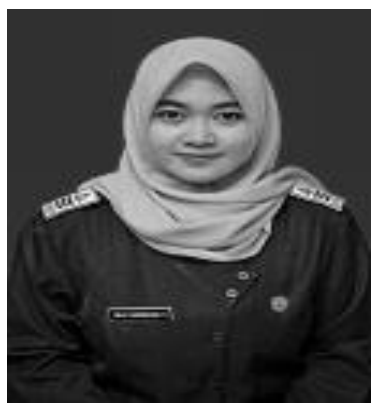

Selvi Anggraeni Supendi, she has been working as a laboratory medical technologist at Pondok Indah Hospital and actively conducting molecular-based examinations. She is a member of the Indonesian Medical Laboratory Technology Association. 